\title{
PENGARUH PENGGUNAAN BAHAN AJAR LEAFLET GEOGRAFI TERHADAP HASIL BELAJAR SISWA SMA NU GENTENG BANYUWANGI
}

\section{THE EFFECT OF GEOGRAPHIC LEAFLETS TEACHING MATERIAL ON STUDENTS' LEARNING OUTCOMES AT SMA NU GENTENG BANYUWANGI}

\author{
M. Rizqon Al Musafiri ${ }^{1}$ \\ ${ }^{1}$ Institut Agama Islam Darussalam Blokagung Banyuwangi \\ email:mrizqonalmusafiri@iaida.ac.id
}

\section{INFORMASI ARTIKEL}

Diterima: 10 November 2021

Direvisi: 29 Desember 2021

Publikasi Online:

31 Desember 2021

\section{KATA KUNCI}

Bahan Ajar Leaflet, Pretest, Posttest, N-Gain, Hasil Belajar

\begin{abstract}
The results of observations on students of class XI IPS 1 and XI IPS 2 at SMA NU Genteng Banyuwangi are still below the minimum completeness score of 75 as many as 35 students. researchers use leaflet teaching materials supplements to improve student learning outcomes. This research was conducted in January 2020 at SMA NU Genteng. The population and sample in this study were students of class XI IPS 1 and XI IPS 2 with the control class selected using cluster random sampling technique. The data used are quantitative to calculate the $N$-gain value from the difference between the pretest and posttest scores. The data were analyzed using $t$ test and Mann Whitney-U. The increase in student learning outcomes is indicated by the difference in the average pretest score of 63.6 and posttest of 84.6. The average value is in accordance with the minimum completeness set by the school, which is 75. In addition, it is also supported by an N-Gain value of 83.2 which shows an increase in student learning outcomes before and after learning is carried out. The percentage of students who dare to express their opinions is $72.9 \%$, students who are active in group work are $78.6 \%$, who are actively asking questions are $76.4 \%$, dare to present the results of discussions are $81.6 \%$ and exchange information are $75.7 \%$. These indicators show the improvement experienced by students. Students who experienced an increase in aspects of knowledge (C1), aspects of understanding (C2) and aspects of analyzing had an average $N$-gain of 71.2 .
\end{abstract}




\section{A B S T R A K}

Hasil pengamatan pada siswa kelas XI IPS 1 dan XI IPS 2 di SMA NU Genteng Banyuwangi masih dibawah nilai ketuntasan minimal yaitu 75 sebanyak 35 siswa. peneliti menggunakan suplemen bahan ajar leaflet untuk meningkatkan hasil belajar siswa. Penelitian ini dilaksanakan pada bulan Januari 2020 di SMA NU Genteng. Populasi dan Sampel dalam penelitian ini siswa kelas XI IPS 1 dan XI IPS 2 dengan kelas kontrol yang dipilih menggunakan teknik cluster random sampling. Data yang digunakan Kuantitatif menghitung nilai $N$-gain dari selisih antara nilai pretest dan postest. Data tersebut dianalisis dengan menggunakan uji $t$ dan Mann Whitney-U. Peningkatan hasil belajar siswa yang ditunjukkan dari perbedaan rata-rata nilai pratest sebesar 63,6 dan posttest sebesar 84,6. Nilai rata-rata tersebut sudah sesuai dengan ketuntasan minimal yang ditetapkan oleh sekolah yaitu 75. Selain itu didukung pula dengan nilai $\mathrm{N}$-Gain sebesar 83,2 yang menunjukkan peningkatan hasil belajar siswa pada saat sebelum dan sesudah pembelajaran dilaksanakan. Prosentase siswa yang berani mengemukakan pendapat sebesar 72,9\%, siswa yang aktif dalam bekerja kelompok sebanyak 78,6\%, yang aktif bertanya sebesar 76,4\%, berani mempresentasikan hasil diskusi sebesar 81,6\% dan bertukar informasi sebesar 75,7\%. Indikator tersebut menunjukkan peningkatan yang dialami oleh siswa. Siswa yang mengalami peningkatan pada aspek pengetahuan (C1), aspek memahami (C2) dan aspek menganalisis memiliki ratarata $\mathrm{N}$-gain sebesar 71,2 .

(C) Heritage: Journal of Social Studies Institut Agama Islam Negeri Jember, Indonesia https:// doi.org/ 10.xxxx/ xxxx

This is an open access article under the CC-BY-SA license

\section{Pendahuluan}

Pendidikan adalah salah satu jenis lambang kebudayaaan manusia yang dinamis dan penuh kemajuan. Demikian itu pula, perubahan terhadap kemajuan sekolah adalah hal yang seharusnya terjadi sesuai tuntutan untuk mengubah kehidupan masyarakat. Perubahan terhadap kemajuan di semua tingkatan pendidikan adalah dasar yang diharapkan dapat terus berlanjut sebagai harapan kepentingan masa depan seorang siswa (Trianto, 2009).

Saat ini, pertimbangan masyarakat terhadap permasalahan sekolah masih sangat rendah, gambaran ini tercermin dalam munculnya bermacam-macam masalah pendidikan yang kemudian mengakibatkan proses belajar siswa masih rendah, instruktur kurang memadai, dan biaya sekolah yang cukup mahal (Muliani, 2009). 
Efek Pendidikan yang kurang bermutu, pendidikan di negara ini kedepan akan lebih buruk dan kurang sesuai untuk bersaing dengan negara-negara non-industri lainnya. Di dalam pengajaran di sekolah, masalah yang sering dihadapi adalah proses belajar, terlepas dari apakah tujuannya tidak sesuai dengan petunjuk dan juga tergantung bagaimana sistem pembelajarannya. Hal ini dialami oleh siswa dan pendidik yang memiliki pilihan yakni mengampu sesuai pada materi pembelajarannya di sekolah khususnya yang berkaitan dengan kondisi bahan ajar siswa sesuai bidang studi. Hal ini dilaksanakan secara konsisten yang ditujukan kepada pendidik dengan menampilkan contoh materi yang benar-benar disampaikan guru dan dapat dipahami oleh siswa secara keseluruhan (Djamarah, S.B. \& Zain, A., 2006).

Realitas di lapangan menunjukkan bahwa proses pembelajaran di sekolah tidak ideal menjadikan hasil yang kurang memuaskan karena terlalu berkonsentrasi pada pembelajaran sains. Banyak elemen yang bisa jadi alasannya hasil belajar siswa rendah di sekolah. Antara lain, model pembelajaran cenderung teks book, kurangnya media pembelajaran, kurangnya terhadap aksesibilitas buku ilustrasi, selain itu hambatan lain yang dialami oleh siswa adalah minat yang rendah dalam membaca dikarenakan karena buku bacaan memiliki halaman yang tebal (Setyono, 2005).

Jika materi pembelajaran yang diberikan oleh guru kurang menarik minat siswa maka hasilnya akan berdampak pada menurunnya hasil belajar. Maka diperlukan bahan ajar yang memadai agar proses pembelajaran menjadi menarik dan membuat siswa termotivasi (Djamarah, S.B. \& Zain, A., 2006). Strategi pembelajaran adalah suatu cara bagaimana siswa melakukan latihan-latihan pembelajaran, misalnya bagaimana mereka bersiap-siap untuk mempertimbangkan, mengambil contoh, latihan belajar mandiri yang dilakukan, desain review mereka, bagaimana mengerjakan tes. Sifat metode pembelajaran akan menentukan sifat hasil belajar yang diperoleh. Metode pembelajaran yang baik akan mendorong pembelajaran yang efektif, jika tidak metode pembelajaran yang buruk akan membuat prestasi menurut atau ketidak puasan pada proses belajar (Al Musafiri, 2017).

Minat belajar siswa yang tidak memadai merupakan salah satu dari beberapa variabel penyebab rendahnya hasil belajar sehingga menyebabkan menurunnya kompetensi dalam pendidikan. Selain itu, bagi siswa yang memiliki kompetensi tinggi namun tidak memiliki sumber belajar yang memadai, hal tersebut juga mempengaruhi hasil belajar siswa. Variabel minat membaca yang tidak dimiliki oleh siswa dikarenakan masih banyak siswa yang benar-benar cerdas tetapi memiliki prestasi akademik yang kurang jika dibandingkan siswa yang kurang memiliki kompetensi. Hal ini terjadi karena siswa memiliki prestasi tinggi selain itu juga memiliki minat memahami pembelajaran yang optimal. 
Hasil pengamatan pada siswa kelas XI IPS 1 dan XI IPS 2 di SMA NU Genteng Banyuwangi menunjukkan kemampuan menguasai materi pembelajaran masih cukup rendah. Rata-rata nilai mata pelajaran geografi pada materi interaksi budaya lokal terhadap budaya nasional masih dibawah nilai ketuntasan minimal yaitu 75. Siswa yang memperoleh nilai kurang dari KKM sebanyak 35 siswa. Dugaan sementara terkait permasalah ini diduga bahan ajar yang digunakan oleh pendidik masih terpaku pada Lembar Kerja Siswa (LKS) dengan pengembangan materi yang masih cukup dangkal, Selain itu jumlah buku teks yang ada masih belum mencukupi untuk semua siswa dan diletakkan di perpustakaan membuat siswa mengalami kesulitan terkait memaksimalkan sumber belajarnya. Untuk itu perlu adanya suplemen bahan ajar yang digunakan untuk melengkapi buku LKS yang ada disekolah yang dapat digunakan sebagai acuan siswa dengan harapan dapat meningkatkan motivasi siswa untuk belajar sehingga secara tidak langsung dapat meningkatkan hasil belajar siswa tersebut.

Berdasarkan permasalahan yang telah dipaparkan sebelumnya salah satu upaya untuk meningkatkan motivasi dan minat belajar siswa SMA NU Genteng dengan menggunakan suplemen bahan ajar yang didesain dengan model leaflet. Agar lebih menarik bagi siswa, leaflet tersebut didesain dengan cermat dan dilengkapi dengan ilustrasi gambar yang dilengkapi dengan penjelasan sederhana, singkat dan tepat sasaran dan mudah dipahami. Kelebihan suplemen bahan ajar yang dimodifikasi dalam bentuk leaflet adalah kemampuan mengakomodasi siswa yang banyak mengalami keterbatasan dapat dipermudah dengan adanya leaflet yang bentuknya simpel.

Materi yang ditampilkan dari leaflet ini diambil pada kelas XI IPS mapel geografi dengan materi interaksi budaya lokal terhadap budaya nasional yang mengangkat budaya Osing sebagai materi utama dalam leaflet tersebut. Leaflet yang diujikan pada siswa SMA NU Genteng ini diharapkan dapat diikuti oleh siswa yang kemampuan berfikir tinggi sampai dengan siswa yang memiliki kemampuan berfikir rendah.

Penelitian yang meneliti tentang pengaruh penggunaan bahan ajar geografi diteliti oleh Yulian Widia Saputra dengan judul pengembangan bahan ajar geografi pada kompetensi dasar memahami atmosfer dan dampaknya terhadap kehidupan di muka bumi kelas x sma/ma semester ii dengan menggunakan pendekatan keruangan. Hasil penelitian tersebut menunjukkan bahwa penggunaan bahan ajar geografi sangat efektif digunakan untuk meningkatkan motivasi dan hasil belajar siswa.

Berdasarkan permasalahan yang disampaikan sebelumnya maka perlunya penelitian pengaruh suplemen bahan ajar geografi pada materi interaksi budaya lokal dengan budaya nasional dilakukan penelitian kepada siswa XI IPS di SMA NU Genteng. 


\section{Metode}

Penulisan artikel dalam penelitian ini menggunakan penelitian eksperimen yang dilaksanakan pada bulan Januari 2020 di SMA NU Genteng. Populasi dan Sampel dalam penelitian ini siswa kelas XI IPS 1 Sebagai Kelas Kontrol dan XI IPS 2 sebagi kelas Eksperimen dengan kelas kontrol yang dipilih menggunakan teknik cluster random sampling.

Penelitian ini didesain dengan menggunakan pretes dan postest yang dilakukan pada kelompok non ekuivalen. Struktur desain penelitian tergambar dalam bagan sebagai berikut:

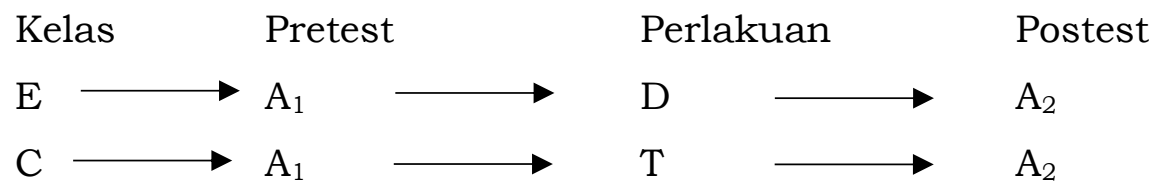

Keterangan:

$\mathrm{E} \quad=$ Kelas Eksperimen

C $\quad=$ Kelas Control

$\mathrm{A}_{1} \quad=$ Pretest

$\mathrm{A}_{2} \quad=$ Postest

$\mathrm{D} \quad=$ Pengaplikasian Suplemen Bahan Ajar

$\mathrm{T}=$ Control

Desain penelitian disesuaikan dari (Riyanto, 2001)

Data yang digunakan pada penelitian ini data Kuantitatif yang menghitung nilai $N$-gain yang diperoleh dari selisih antara nilai pretest dan postest. Data tersebut dianalisis dengan menggunakan uji t dan Mann Whitney-U, serta data deskripsi yang diperoleh dari angket respon siswa terhadap suplemen bahan ajar geografi dan lembar pengamatan kegiatan siswa.

\section{Hasil}

Berdasarkan penelitian yang dilakukan, hasil penelitian ini dapat dilihat pada grafik dibawah ini. 


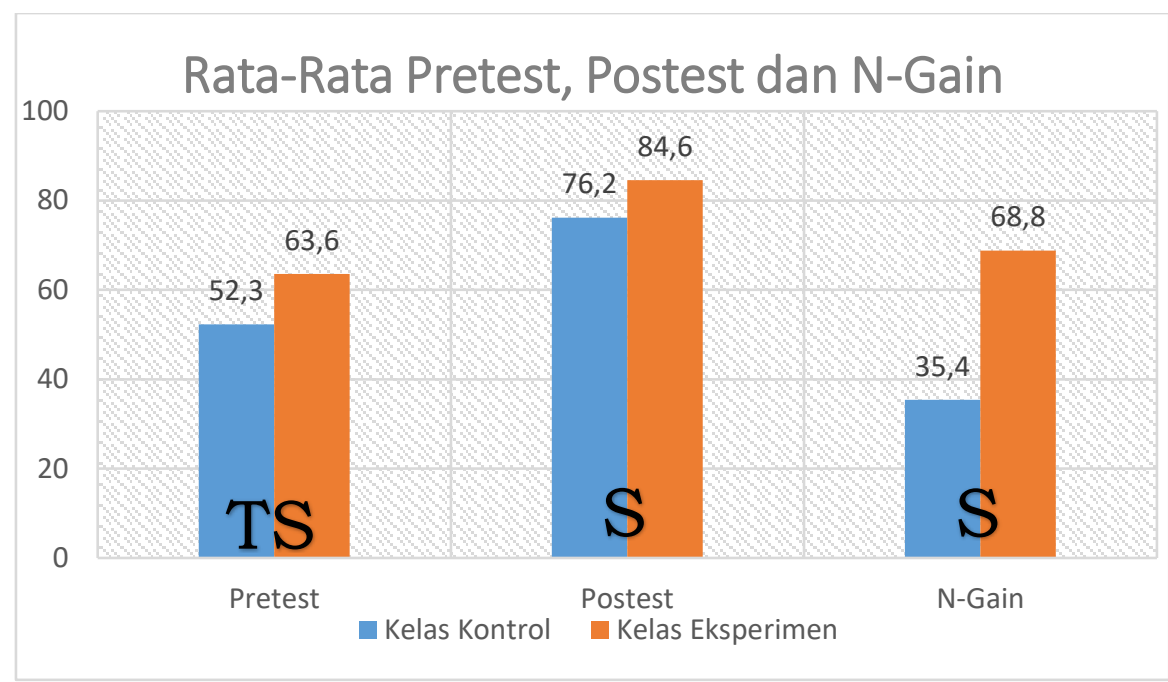

Keterangan (Grafik 1):

TS : Tidak Signifikan Perbedaannya

S : Signifikan Perbedaanya

Sesuai dengan grafik 1 dapat dilihat memiliki perbedaan yang terlihat bahwa hasil pretest di kelas eksperimen dan kelas kontrol memiliki hasil yang tidak signifikan, hal ini menunjukkan bahwa siswa di masing-masing kelas memiliki kemampuan yang hampir sama. Sedangkan untuk nilai post test dan N-gain normal pada kedua kelas itu memiliki hasil yang mencolok dengan kelas eksperimen memiliki hasil lebih tinggi dibandingkan dengan kelas kontrol.

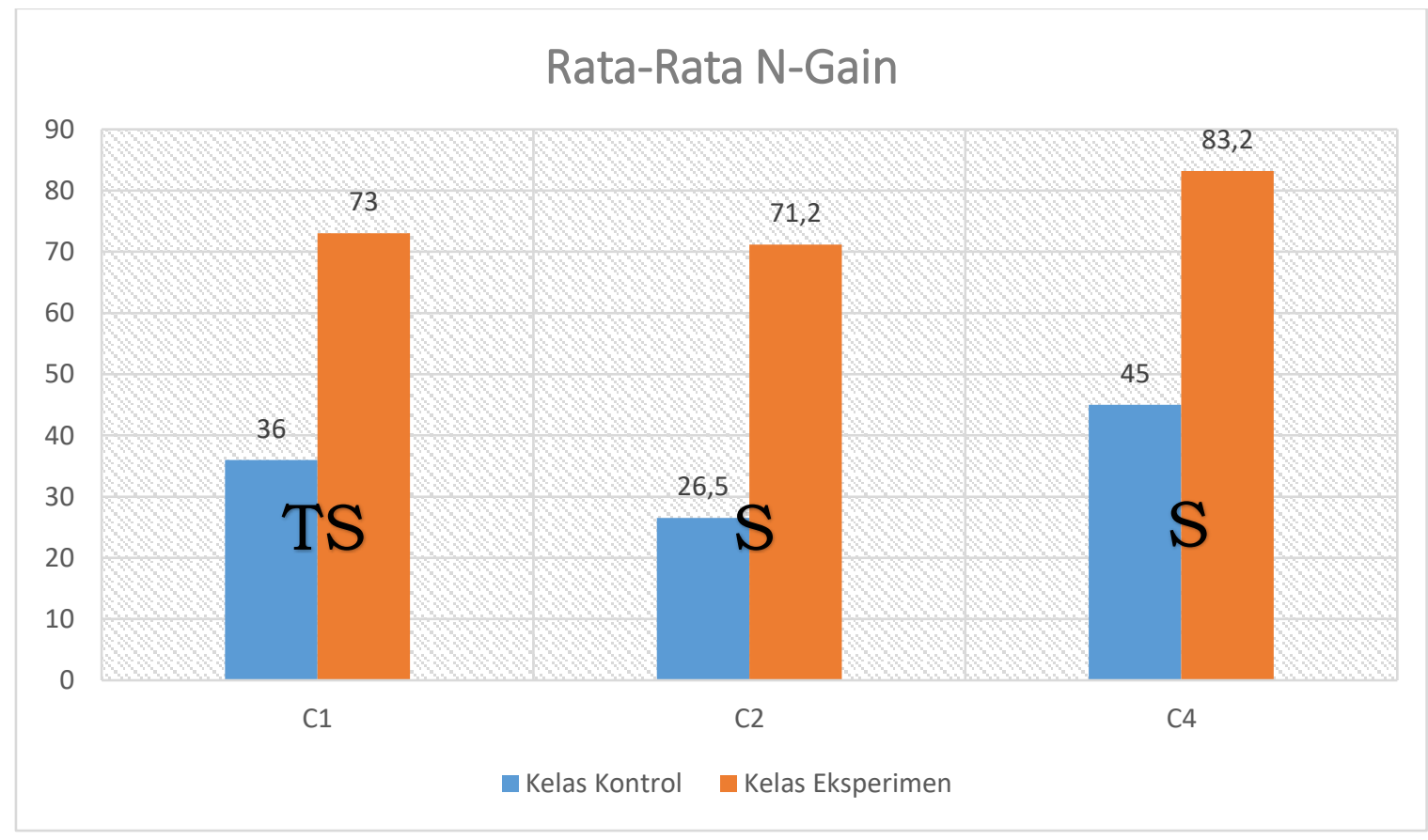

Grafik 2: Rata-Rata N-Gain pada siswa Kelas Eksperimen dan Kelas Kontrol pada Indikator $\mathrm{C} 1, \mathrm{C} 2, \mathrm{C} 4$ 
Grafik 2 dapat dianalisis bahwa Rata-Rata $N$-gain pada indikator C1 di kedua kelas menunjukkan tidak memiliki perbedaan yang signifikan sedangkan indikator C2 dan C4 yang diujikan di kedua kelas memiliki perbedaan yang signifikan.

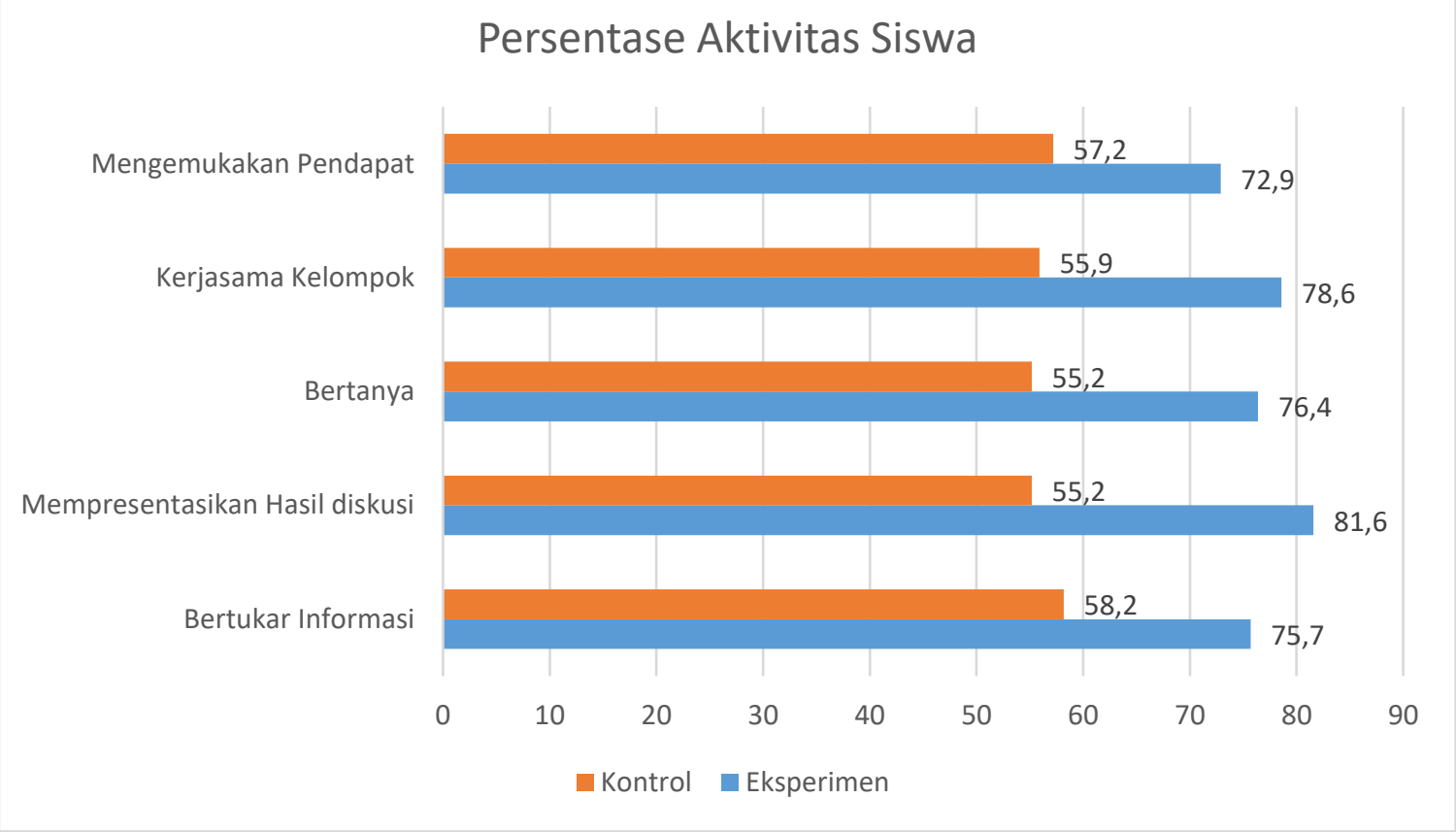

Grafik 3: Persentase Aktivitas siswa dan pengolahannya

Berdasarkan grafik yang telah dipaparkan di atas serta pengolahan yang dilakukan diperoleh kesimpulan bahwa aktivitas belajar siswa pada kelas eksperimen lebih tinggi dibandingkan dengan kelas kontrol dengan rata-rata nilai sebesar $20,7 \%$.

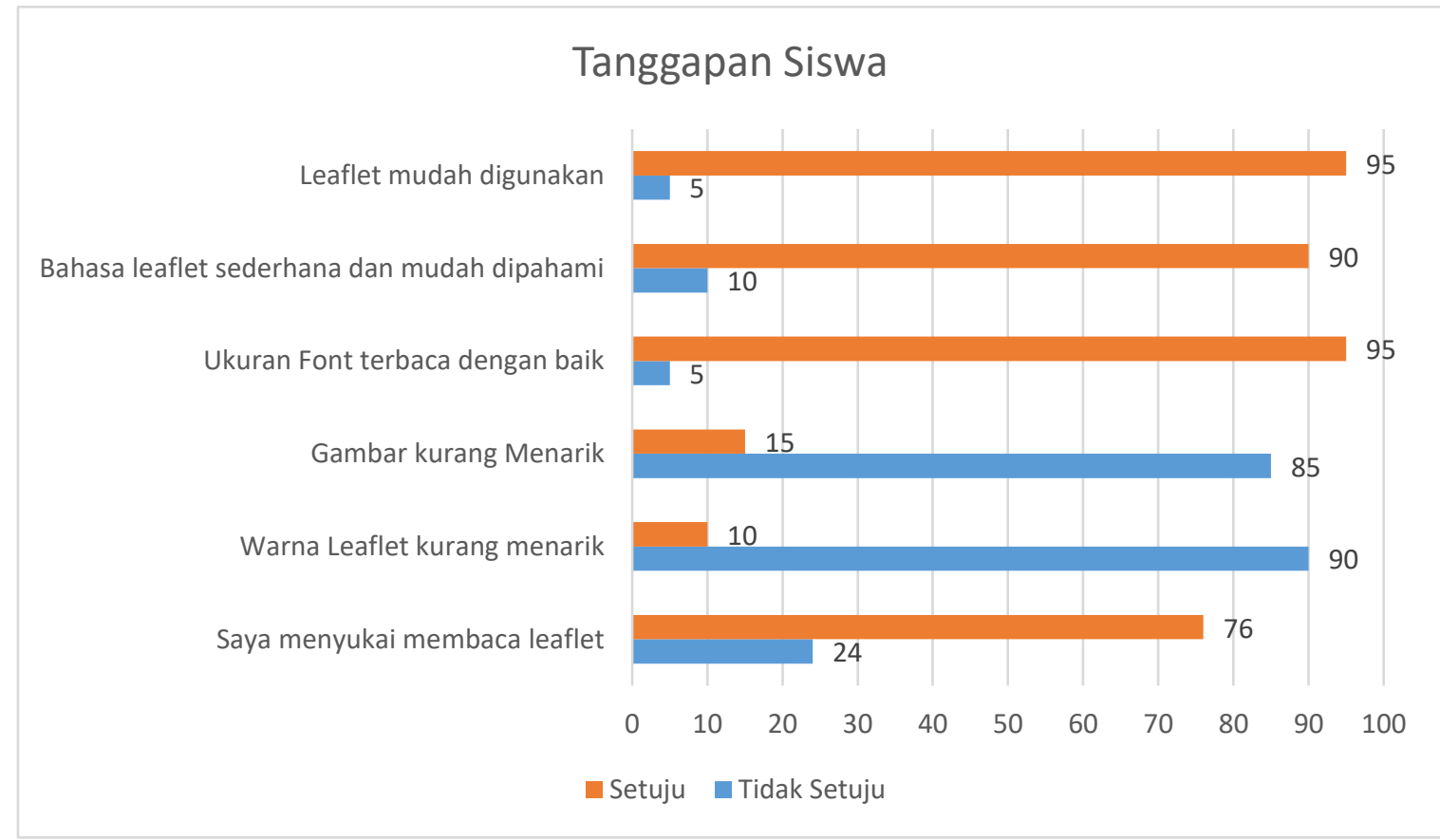


Gambar 4: Angket tanggapan siswa terhadap suplemen bahan ajar geografi (leaflet)

Berdasarkan angket yang telah dibagikan kepada siswa untuk mengetahui hal-hal yang dapat diperbaiki menunjukkan bahwa bahasa yang digunakan pada leaflet ini mudah dipahami dikarenakan bahasanya dibuat sederhana. Hal ini ditunjukkan pada hasil angket menyatakan bahwa 10\% siswa menyatakan tidak setuju sedangkan yang 90\% siswa menyatakan setuju.

Pada pertanyaan leaflet mudah digunakan menunjukkan bahwa 5 siswa menyatakan tidak setuju dan 95\% siswa menyatakan setuju, hal ini dapat disimpulkan bahwa leaflet tersebut mudah digunakan oleh siswa. Begitu juga pada pernyataan ukuran font pada keterbacaan leaflet menunjukkan bahwa dapat dibaca dengan baik karena dari hasil angket menunjukkan bahwa 5\% siswa mengatakan tidak setuju dan 95\% menyatakan setuju.

Gambar pada leaflet juga menarik didapatkan dari pernyataan siswa yang menujukkan bahwa 85\% siswa menyatakan gambar yang terdapat pada leaflet menarik siswa untuk membaca. Didukung dengan warna leaflet yang menarik sehingga siswa menyukai membaca leaflet yang digunakan sebagai suplemen bahan ajar geografi pada siswa SMA.

\section{Diskusi}

Berdasarkan analisis yang dapat dilihat pada grafik 1 dapat disimpulkan terdapat peningkatan hasil belajar siswa yang ditunjukkan dari perbedaan rata-rata nilai pretest sebesar 63,6 dan posttest sebesar 84,6. Nilai rata-rata tersebut sudah sesuai dengan ketuntasan minimal yang ditetapkan oleh sekolah yaitu 75. Selain itu didukung pula dengan nilai $N$-Gain sebesar 83,2 yang menunjukkan peningkatan hasil belajar siswa pada saat sebelum dan sesudah pembelajaran dilaksanakan. Dapat diperoleh kesimpulan bahwa penggunaan suplemen bahan ajar geografi dalam bentuk leaflet ini memiliki pengaruh yang signifikan dalam meningkatkan hasil belajar siswa pada materi pokok integrasi budaya lokal terhadap budaya nasional yang diajarkan di kelas XI IPS.

Suplemen bahan ajar geografi dalam bentuk leaflet memiliki pengaruh dalam meningkatkan hasil belajar siswa karena dapat memperjelas materi Interaksi budaya lokal terhadap budaya nasional yang dijelaskan dengan ringkas dan mudah 
dipahami sehingga meningkatkan motivasi belajar yang ditunjukkan pada grafik 3 dengan prosentase siswa yang berani mengemukakan pendapat sebesar 72,9\%, siswa yang aktif dalam bekerja kelompok sebanyak 78,6\%, yang aktif bertanya sebesar 76,4\%, berani mempresentasikan hasil diskusi sebesar 81,6\% dan bertukar informasi sebesar $75,7 \%$.

Peningkatan secara umum terhadap hasil belajar siswa dapat dibuktikan pada indikator kemampuan kognitif siswa pada aspek pengetahuan (C1), memahami (C2) dan menganalisis (C4). Indikator tersebut menunjukkan peningkatan yang dialami oleh siswa. Data $N$-gain yang dipaparkan pada grafik ditas menunjukkan angka sebesar 73 untuk indikator (C1) pada aspek pengetahuan. Indikator C1 menunjukkan kemampuan siswa dalam menajamkan pengetahuan terhadap materi yang diajarkan. Agar peningkatan pada indikator ini dapat tercapai diperlukan latihan pada siswa untuk menjawab pertanyaan yang ada di LKS pada materi interaksi budaya lokal terhadap budaya nasional.

Siswa yang mengalami peningkatan pada indikator pengetahuan (C1) dikarenakan soal tes yang dikerjakan mampu menggali pengetahuan siswa sehingga materi yang disampaikan dapat dipahami dengan baik oleh siswa, sehingga proses pengerjaan latihan soal dapat dijawab dengan mudah. Kesimpulan yang didapatkan dalam menjawab soal tes yang mengutamakan pengetahuan cenderung dapat dikerjakan dengan mudah dibandingkan dengan soal yang menggunakan indikator C2 dan C4. Pengetahuan yang diperoleh siswa juga dibantu dengan membaca leaflet dan didiskusikan dengan teman di kelompok yang memungkinkan adanya aktivitas pertukaran informasi yang memungkinkan menambah pengetahuan antar siswa. Kesimpulan ini didukung oleh pendapat (Slameto, 2003) yang menyatakan bahwa kegiatan belajar mengajar yang dilakukan oleh guru dapat menimbulkan aktivitas dalam pemikiran maupun perbuatan sehingga siswa berpartisipasi aktif maka pengetahuan itu dianggap dapat diterima dengan baik oleh siswa.

Siswa yang mengalami peningkatan pada aspek memahami (C2) memiliki rata-rata $\mathrm{N}$-gain sebesar 71,2. Indikator $\mathrm{C} 2$ dirumuskan untuk memahami kemampuan siswa teterhadap permasalahan dalam materi pembelajaran. Kemampuan siswa ini meningkat karena sering mengerjakan Lembar Kerja Siswa yang soal-soalnya memfokuskan pada kemampuan memahami (C2). Kemampuan memahami ini mengalami peningkatan dipengaruhi pula oleh pembelajaran yang 
menggunakan leaflet dalam memahami materi yang diajarkan. Desain leaflet yang sangat menarik didukung dengan contoh gambar serta contoh pada sub materi dapat membantu siswa memahami pertanyaan yang diberikan kepada siswa. Hal ini pula didukung dengan keaktifan belajar siswa dan kemampuan kerja sama kelompok yang ditunjukkan ketika berdiskusi, sehingga proses pemahaman materi menjadi lebih mudah. Biasanya aktivitas siswa mengalami penurunan ketika sumber belajar siswa yang diberikan guru kurang menarik minat siswa (Djamarah, S.B. \& Zain, A., 2006). Selain itu pemamparan materi yang ada dalam leaflet disajikan secara terstruktur dengan didukung data pada grafik 4 dimana 90\% siswa setuju jika materi pembelajaran disusun secara terstruktur yang membuat siswa menjadi mudah dalam memahami materi yang telah disusun.

Penjelasan pada aspek analisis (C4) memiliki rata-rata $\mathrm{N}$-gain sebesar 83,2 dimana hal ini menunjukkan kemampuan siswa dalam menganalisis sebuah masalah dalam materi pembelajaran. Peningkatan kompetensi siswa dalam menganalisis permasalahan tersebut dapat terlihat bahwa siswa mampu menguasai bahan pembelajaran yang disampaikan. Meningkatnya kemampuan siswa dalam menganalisis materi ini diperoleh dari penggunaan suplemen bahan ajar geografi dalam bentuk leaflet yang membuat siswa mampu memahami masalah yang disampaikan. Jika siswa mampu menganalisis materi yang telah dijelaskan sebelumnya dengan didukung pada pengerjaan pertanyaan yang diberikan diperoleh kesimpulan bahwa kemampuan analisis siswa mengalami peningkatan. Kemampuan analisis memiliki arti dapat menguraikan sebuah permasalahan dan kondisi tertentu kedalam unsur dan komponen yang menyusunnya sehingga siswa merasa mudah untuk menganalisis soal yang diujikan (Daryanto, 2016).

Berdasarkan hasil penelitian yang dilakukan di SMA NU Genteng tentang suplemen bahan ajar geografi dengan menggunakan leaflet yang berisi materi interaksi budaya lokal dengan budaya nasional yang berisikan tentang keseuaian warna, gambar, bahasa dan ukuran tulisan dimana semua siswa setuju dengan mayoritas hasil angket diatas 85\%. Hasil keterangan siswa juga diperoleh bahwa suplemen bahan ajar leaflet dapat dijadikan alternatif sumber belajar pada mata pelajaran geografi kelas XI IPS. Selain itu pada paparan data diatas diketahui nilai posttest dan pratest serta $N$-gain pada materi interaksi budaya lokal terhadap budaya 
nasional menunjukkan bahwa penggunaan suplemen bahan ajar geografi dengan leaflet memiliki pengaruh terhadap aktivitas dan hasil belajar siswa.

\section{Kesimpulan}

Nilai rata-rata tersebut sudah sesuai dengan ketuntasan minimal yang ditetapkan oleh sekolah yaitu 75 . Selain itu didukung pula dengan nilai N-Gain sebesar 83,2 yang menunjukkan peningkatan hasil belajar siswa pada saat sebelum dan sesudah pembelajaran dilaksanakan. Suplemen bahan ajar geografi dalam bentuk leaflet memiliki pengaruh dalam meningkatkan hasil belajar siswa karena dapat memperjelas materi Interaksi budaya lokal terhadap budaya nasional yang dijelaskan dengan ringkas dan mudah dipahami sehingga meningkatkan motivasi belajar yang ditunjukkan pada grafik 3 dengan persentase siswa yang berani mengemukakan pendapat sebesar 72,9 \%, siswa yang aktif dalam bekerja kelompok sebanyak 78,6\%, yang aktif bertanya sebesar 76,4\%, berani mempresentasikan hasil diskusi sebesar $81,6 \%$ dan bertukar informasi sebesar 75,7\%.

Indikator tersebut menunjukkan peningkatan yang dialami oleh siswa. Siswa yang mengalami peningkatan pada aspek memahami (C2) memiliki rata-rata $N$-gain sebesar 71,2. Penjelasan pada aspek analisis (C4) memiliki rata-rata $N$-gain sebesar 83,2 dimana hal ini menunjukkan kemampuan siswa dalam menganalisis sebuah masalah dalam materi pembelajaran. Berdasarkan hasil penelitian yang dilakukan di SMA NU Genteng tentang suplemen bahan ajar geografi dengan menggunakan leaflet yang berisi materi interaksi budaya lokal dengan budaya nasional yang berisikan tentang keseuaian warna, gambar, bahasa dan ukuran tulisan dimana semua siswa setuju dengan mayoritas hasil angket diatas 85\%.

\section{Referensi}

Al Musafiri, M. R. (2017). Pengaruh Minat Baca Mahasiswa Terhadap Hasil Belajar Pada Mahasiswa Bimbingan Konseling Islam IAI DArussalam Blokagung. Jurnal Darussalam: Jurnal Pendidikan, Komunikasi dan Pemikiran Hukum Islam, 466-478.

Asnawi, S. (2002). Teori Motivasi. Jakarta: Studia Press.

Daryanto. (2016). Hasil Belajar Siswa. Jakarta: Rineka Cipta.

Dimyati, M. (1990). Psikologi Suatu Pengantar. Jakarta: BPFF.

Djamarah, S.B., \& Zain, A. (2006). STrategi Belajar Mengajar. Jakarta: RIneka CIpta.

Djiwandono, S. (2002). Psikologi Pendidikan. Jakarta: Grasindo. 
Galloway, C. (1976). Psychology for Learning Teacher. New York: Mc. Grow Hill.

Geiser, S., \& Studley, R. (2002). Educational Assessment. California: UC and The SAT.

IAIDA. (2021). Rencana Strategis Institut Agama Islam Darussalam Blokagung Banyuwangi. Banyuwangi: IAIDA Press.

Muliani. (2009, April 16). Masalah Pendidikan di Indonesia. Retrieved from Univeristas Bangka Belitung: http//:www.ubb.ac.id

Purwanto, N. (1998). Psikologi Pendidikan. Bandung: PT. Remaja Rosdakarya.

Purwodarminto, W. (1994). Kamus Umum Bahasa Indonesia. Jakarta: Balai Pustaka.

Riyanto, Y. (2001). Metodologi Penelitian Pendidikan. Surabaya: SIC.

Sardiman, A. (2001). Interaksi dan Motivasi Belajar Mengajar. Jakarta: PT. Rajawali Pers.

Setyono, B. (2005). Penyusunan Bahan Ajar. JAkarta: Rineka Cipta.

Slameto. (2003). Belajar dan Faktor-Faktor yang Mempengaruhinya. Jakarta: RIneka Cipta. 